\title{
Bioclimatic ArChitecture APPROACH To ENERgy EFFiCIENT SCHOOL BUILDING CONCEPTS
}

\section{Pendekatan Arsitektur Bioklimatik Pada KonSEP BANGUNAN SEKOLAH HEMAT ENERGI}

\author{
Lia Amelia Megawati ${ }^{1 *}$, Akhmad Akromusyuhada ${ }^{2}$ \\ Program Studi Arsitektur, Sekolah Tinggi Teknologi Pelita Bangsa ${ }^{1}$ \\ liaameliamegawati@pelitabangsa.ac.id* \\ Program Studi Arsitektur, Sekolah Tinggi Teknologi Pelita Bangsa ${ }^{2}$ \\ akhmad.akrom@pelitabangsa.ac.id
}

\begin{abstract}
Bioclimatic architecture is an integrated concept in building design where the structure, space and building construction systems can guarantee comfortable conditions for the occupants. This concept was developed in the building of SMU Al Wahid Kabupaten Tasikmalaya which is physically a school building far from comfortable. The form of school buildings does not support the implementation of good quality teaching and learning activities, so that redesign is needed to support the comfort of school building users. Contoured area locations, beautiful environment and adequate air temperature are sufficient to support the application of bioclimatic architectural concepts. To obtain accurate primary data, the Post Occupancy Evaluation method is used. This study focused on building users, needs and provided insight into the consequences of existing designs. The evaluation results will be used as planning criteria in the program and subsequent design. Bioclimatic architecture is implemented in the hope of increasing the comfort of users of school facilities so that the process of teaching and learning can run optimally.
\end{abstract}

Keywords : Bioclimate, School Building, Energy Efficient

\section{PENDAHULUAN}

Arsitektur bioklimatik merupakan salah satu pendekatan yang dapat memberikan pandangan tersendiri bagi seorang arsitek untuk mendapatkan penyelesaian desain dengan memperhatikan hubungan antara bentuk arsitektur dengan lingkungan. Arsitektur Bioklimatik adalah suatu pendekatan desain yang mengarahkan arsitek untuk melakukan penyelesaian desain dengan mempertimbangkan hubungan antara bentuk arsitektur dengan lingkungannya, dalam hal ini iklim daerah tersebut (Dewangga, 2016). Bioklimatik berasal dari bahasa asing yaitu Bioclimatology. Menurut Yeang (1994), "Bioclimatology is the study of the relationship between climate and life, particulary the effect of climate on the health of activity of living things". Bioklimatik adalah ilmu yang mempelajari antara hubungan iklim dan kehidupan terutama efek dari iklim pada kesehatan dan aktivitas sehari-hari. Bangunan bioklimatik adalah bangunan yang bentuk bangunannya disusun oleh desain teknik hemat energi yang berhubungan dengan iklim setempat. 
Rosang dalam Cahyaningrum (2017) mengungkapkan bahwa Arsitektur Bioklimatik merupakan seni merancang bangunan dengan metode hemat energi yang memperhatikan iklim setempat dan memecahkan masalah iklim dengan menerapkan pada elemen bangunan. Tujuan dari arsitektur bioklimatik itu sendiri menciptakan suatu lingkungan dan bangunan yang dirancang untuk sepenuhnya menutupi kebutuhan energi tanpa menyebabkan kerusakan pada lingkungan sekitar. Arsitektur bioklimatik lebih berfokus pada iklim sebagai konteks pembangkit tenaga utama, tidak membahayakan lingkungan sekitar, menggunakan energi minimal sebagai targetnya sendiri, dan tanpa mengurangi kenyamanan penggunanya. Secara umum, prinsip desain bioklimatik adalah: hemat energi (Conserving Energy), memperhatikan kondisi iklim (Working with Climate), ramah lingkungan (Minimizing New Resources), merespon keadaan tapak dari bangunan (Respect for tapak), dan nyaman bagi penghuni bangunan tersebut (Respect for user). Kelima prinsip dasar arsitektur bioklimatik tersebut kemudian disederhanakan kembali menjadi tiga prinsip desain arsitektur bioklimatik yaitu hemat energi, memperhatikan kondisi iklim, dan ramah lingkungan (Cahyaningrum, 2017).

Sekolah Menengah Umum Plus Al Wahid Kabupaten Tasikmalaya merupakan salah satu sekolah penyelenggara pendidikan menengah yang berlokasikan di Kabupaten Tasikmalaya. SMA Plus AlWahid ini berdiri tahun 2000 di kampung Wanasigra, Kabupaten Tasikmalaya. Sejak berdirinya SMA Al- Wahid berhasil meraih beberapa penghargaan dalam Olimpiade tingkat kabupaten Tasikmalaya. Bahkan sampai saat ini banyak tersebar lulusan Al-Wahid di Perguruan Tinggi Negeri dan Perguruan Tinggi Swasta.

Bangunan sekolah sangat berperan penting terutama dalam tercapainya visi misi pendidikan nasional. Setiap hari bangunan sekolah digunakan oleh pengguna yaitu siswa, guru dan staf untuk melakukan proses belajar mengajar. Untuk menunjang kegiatan belajar mengajar bangunan sekolah harus memiliki sarana dan prasarana yang memadai. Kelayakan dan kenyamanan bangunan sangat penting melihat intensitas kegiatan yang cukup tinggi yaitu sekitar 7-8 jam/hari. Oleh karena itu diperlukan bangunan sekolah yang ideal dan sesuai peruntukannya.

Berdasarkan Peraturan Menteri Pendidikan Nasional Republik Indonesia No. 24 Tahun 2007, ada beberapa persyaratan yang harus dipenuhi pada bangunan gedung sekolah diantaranya:

a. Persyaratan Keselamatan, meliputi: (a) Memiliki struktur yang stabil dan kukuh sampai dengan kondisi pembebanan maksimum dalam mendukung beban muatan hidup dan beban muatan mati, serta untuk daerah/zona tertentu kemampuan untuk menahan gempa dan kekuatan alam lainnya, (b) Dilengkapi dengan sistem proteksi pasif dan/atau proteksi proaktif untuk mencegah dan menanggulangi bahaya kebakaran dan petir.

b. Persyaratan Kesehatan, meliputi: (a) Mempunyai fasilitas secukupnya untuk ventilasi udara dan pencahayaan yang memadai, (b) Memiliki sanitasi didalam dan diluar bangunan gedung untuk memenuhi kebutuhan air bersih, pembuangan air kotor atau air limbah, kotoran dan tempat sampah, serta penyaluran air hujan, (c) Bahan bangunan yang aman bagi kesehatan pengguna bangunan gedung dan tidak menimbulkan dampak negatif terhadap lingkungan.

c. Persyaratan Kenyamanan, meliputi: (a) Bangunan gedung mampu meredam getaran dan kebisingan yang menggagu kegiatan pembelajaran, (b) Setiap ruangan memiliki temperatur dan kelembaban yang tidak melebihi kondisi diluar ruangan, (c) Setiap ruangan dilengkapi dengan lampu penerangan

d. Kelengkapan Sarana dan Prasarana. Sebuah SMA/MA sekurang-kurangnya memiliki prasarana diantaranya Ruang kelas, Ruang perpustakaan, Ruang laboratorium biologi, Ruang laboratorium fisika, Ruang laboratorium kimia, Ruang laboratorium komputer, Ruang laboratorium bahasa, Ruang pimpinan, 
Ruang guru, Ruang tata usaha, Tempat beribadah, Ruang konseling, Ruang UKS, Ruang organisasi kesiswaan, Jamban, Gudang, Ruang sirkulasi, Tempat bermain/berolahraga.

Secara fisik bangunan Sekolah Menengah Umum Plus Al Wahid Kabupaten Tasikmalaya terlihat sama seperti bangunan sekolah menengah pada umumnya di Indonesia. Namun, secara fisik bangunan ini kurang memadai untuk menunjang kegiatan belajar mengajar. Ventilasi yang kurang baik, ruang kelas yang panas pada jam tertentu, ruang perpustakaan yang pengap, sanitasi yang tidak baik, serta minimnya penghijauan menjadi faktor yang mengakibatkan rendahnya kenyamanan pengguna bangunan. Perlu adanya desain ulang untuk memperbaiki kondisi bangunan yang tidak nyaman tersebut serta penyesuaian konsep bangunan dengan iklim dan lingkungan sekitarnya.

\section{METODE PENELITIAN}

Untuk mendapatkan data primer yang akurat digunakan metode pengumpulan data dengan Metode Kuisioner yang disebar pada pengguna bangunan sekolah. Metode Evaluasi pasca - huni (Post Occupancy Evaluation) digunakan dalam menemukan permasalahan yang terjadi pada bangunan sekolah ini. Post Occupancy Evaluation merupakan suatu bagian dari rentetan kegiatan di dalam proses pembangunan dimana kajian atas suatu bangunan yang telah dipergunakan (dihuni) dilakukan secara seksama atau sistematika untuk menilai apakah kinerja bangunan tersebut sejalan dengan kriteria perancangannya (Danisworo, 1989).

Post Occupancy Evaluation adalah proses penilaian bangunan secara sistematik dan menyeluruh setelah dibangun dan digunakan. Menurut Sudibyo (1989) Post Occupancy Evaluation (POE) atau Evaluasi Pasca Huni merupakan kegiatan berupa peninjauan (pengkaijan) kembali (evaluasi) terhadap bangunan-bangunan dana tau lingkungan binaan yang telah dihuni. Robinowitz dalam Moore (1994) memilih POE dalam tiga aspek yaitu: fungsional, teknis dan perilaku (behavioral). Dalam pelaksaan kegiatan POE, evaluator dapat melakukan satu atau lebih aspek yang hendak dievaluasi. Tentu saja semakin banyak aspek yang akan dievaluasi semakin banyak waktu, biaya dan tenaga serta perhatian yang harus diberikan. Demikian juga dengan metode dan strateginya, serta prosedur penelitiannya (Sudibyo, 1989).

\subsection{Aspek Fungsional}

Aspek fungsional yang dimaksud disini adalah menyangkut segala aspek bangunan (dan atau seting di lingkungan binaan) yang secara langsung mendukung kegiatan pemakai dengan segala atributnya (sebagai individu dan kelompok). Dinding, lantai, langit-langit tidak secara langsung berpengaruh pada kegiatan pemakai. Tata ruang dan pengaturan lintasan misalnya, mempengaruhi kegiatan pemakai dan berlangsungnya fungsi secara keseluruhan. Kesalahan dalam perancangan dapat menimbulkan tidak efisiennya suatu bangunan. Akibat selanjutnya, yang paling serius adalah jika pemakai tidak dapat melakukan adaptasi terhadap lingkungan binaan tadi. Sudibyo (1989).

Perancangan bangunan yang menekankan fungsi, antara lain akan berpedoman pada kesesuaian antara area kegiatan dengan segala kegiatan yang berlangsung didalamnya. Jika ini yang terjadi maka disanalah problem-problem fungsional akan muncul dan menjadi menjadi titik perhatian evaluasi. Beberapa hal yang merupakan bagian kritis aspek fungsional menurut Sudibyo (1989) antara lain:

a. Pengelompokan fungsi: menyangkut konsep pengelompokan atau pemisahan fungsi-fungsi yang berlangsung didalam suatu bangunan. Hal ini mempengaruhi kelancaran pekerjaan dan komunikasi kesesuaian. Pola kegiatan yang berlangsung pada suatu wadah dengan lingkungan binaan yang ditempatinya akan menunjukkan tingkat efisiensi bangunan atau lingkungan binaan tersebut.

b. Sirkulasi merupakan salah satu kunci bagi fungsi bangunan. Tidak jarang kesalahan pengaturan sirkulasi menyebabkan ada daerah yang terlalu sepi dan ada daerah yang terlalu padat. 
Kalaupun bukan kesalahan awal dari perancangannya, misal terjadi perubahan organisasi yang mengakibatkan perubahan pola sirkulasi dan komunikasi kerja, dapat mengakibatkan ketidakseimbangan atau ketidaksesuaian dengan lingkungan binaan yang ditempatinya. Pada bangunan yang menekankan pertimbangan ekonomi (seperti rental office, apartemen dan lain-lain), meminta perhatian ekstra dalam pengaturansirkulasi agar tingkat efisiensi bangunan dapat dicapai secara maksimal.

c. Faktor manusia; ini terutama akan menyangkut segi-segi perancangandan standar. Bagaimana kesesuaiannya antara konfigurasi, material dan ukuran terhadap pemakainya. Sebagai salah satu pedoman pabrikasi sering menimbulkan permasalahan jika ditetapkam pada dua kelompok masing-masing yang berbeda (ukuran keadaan fisiknya). Yang sering diangkat sebagai objek evaluasi disini adalah kondisi spesifik dari fasilitas untuk kelompok/ orang-orang yang khusus (misalnya cacat, orang tua dan anak-anak).

d. Fleksibilitas dan perubahan. Banyak bangunan yang mengalami perubahan fungsi. Keadaan ini akan mempengaruhi sikap perancang dalam mengambil keputusan rancangannya. Evalusi terhadap perubahan fungsi (mungkin susunan/organisasi dan kegiatan) memberi masukan yang sangat berguna bagi perancang. Fleksibilitas menjadi pertimbangan rancangan tata ruang dan prasarana.

\subsection{Aspek Teknis}

Pemilik bangunan antara lain mengharapkan bangunan aman, nyaman dan berumur panjang. Harapan tersebut secara langsung akan menyangkut kondisi fisik bangunannya meliputi struktur, ventilasi, sanitasi dan pengaman bangunan serta sistem penyangganya (Sudibyo, 1989). Beberapa hal yang menjadi perhatian penting evaluator POE antara lain:

a. Dinding luar, terutama untuk bengunan di daerah tropis (khususnya bangunan berlantai banyak) penyelesaian dinding luar bangunan meminta perhatian ekstra dari perancang karena pengaruh iklim di daerah tropis lebih banyak dibanding daerah non tropis. Hujan, debu, jamur, matahari dan sebagainya sangat berpengaruh terhadap elemen bangunan ini. Lebih jauh problem perawatan yang selanjutnya membawa pada pertimbangan pembiayaan, sehingga problem yang satu ini berpegaruh terhadap problem lainnya.

b. Atap, aspek teknis dari atap terlebih lagi di daerah tropis sangat penting untuk dievaluasi. Atap dalam kaitan dengan fungsinya (bukan aspek fungsi) sendiri, komponen materialnya serta penyelesaian arsitektral (misal pembukaan-pembukaan pada tap untuk tujuan penghawaan dan penyinaran). Sering timbulnya masalah atap pada bangunan patut menjadi perhatian penting bagi evaluator, juga perancangnya.

c. Struktur, kerusakan pada struktur dapat terjadi selama masa penghunian atau karena kesalahan pada masa membangun serta kurang cermatnya perancangan. Evaluasi terhadap struktur walau jarang dilakukan namun suatu saat sangat diperlukan. Kerusakan struktur akibat kesalahan perancangan bisa terjadi misalnya ketidaksesuaian antara sifat perilaku tanah penyangga dengan sistem dan atau material struktur. Kesalahan dalam tahap pembangunan dapat terjadi karena kesengajaan atau ketidaktauan dalam persyaratan teknis. Sedang kesalahan dalam masa penghunian mungkin terjadi karena ketidaksesuaian beban nyata dengan beban yang rancang (misal karena perubahan fungsi).

d. Penyelamatan terhadap kebakaran, perhatian dalam melakukan evakuasi teruatama dikaitkan dengan perancangan akan melibatkan perletakkan (tangga penyelamat dan pemadam kebakaran) sirkulasi dan material bangunan, pemakaian terlalu sering atau sebaliknya karena tidak pernah dipakai dapat menimbulkan masalah jika terjadi kebakaran. Salah satu keuntungannya adalah daoat memberi masukan bagi 
peraturan bangunan setempat (building codes).

e. Penyesuaian interior, seperti dinding dalam, lantai dan langit-langit sangat penting untuk dievaluasi karena merupakan bagian paling sering berhubungan dengan penggunaan bangunan. Kesalahan perancangan sering ditemukan pada evaluasi. Lantai yang terlihat kotor atau pecah-pecah dapat terjadi karena kesalahan perancangan atau pada pelaksanaan pemasangannya. Muncul produk cat tembok yang dapat dibersihkan dengan kain basah kalau kotor, sebagai salah satu tindakan nyata dari studi yang bersifat evaluatif.

f. Penerangan pengkondisian ruang dan akustik, merupakan bagian dari aspek teknis lingkungan binaan yang juga sering dijadikan tajuk evaluasi. Kesimpulan sebagai hasil evaluasi sering dimanfaatkan oleh industri konstruksi dan indutri lain yang berkaitan dengan kebutuhan manusia dalam menghuni bangunan. Contoh sederhana yang dapat dijumpai misalnya mengalirkan produk industrielektronika yang memerlukan energi kecil. Hal ini sebagai antisipasi terhadap konservasi energi, industri berlomba memecahkan problemproblem dengan operasi yang lebih kecil diraih manfaat yang besar.

\subsection{Aspek Perilaku}

Aspek perilaku menghubungkan kegiatan pemakai dengan lingkungan fisiknya. Evaluasi perilaku adalah mengenai bagaimana kesejahteraan sosial dan psikologis pemakai dipengaruhi oleh rancangan bangunan. Beberapa permasalahan perilaku yang perlu diperhatikan misalnya proximity dan teritoriality, privasi dan interaksi, persepsi, citra dan makna, kognisi dan orientasi. (Sudibyo, 1989)

Penelitian ini difokuskan pada pengguna bangunan, kebutuhan dan menyediakan wawasan mengenai konsekuensi desain yang sudah ada. Ketiga aspek tersebut menunjukkan kemampuan bangunan mewadahi kegiatan penggunanya. Hasil evaluasi tersebut akan digunakan sebagai kriteria perencanaan dalam program dan perancangan selanjutnya.

Evaluasi pasca-huni memiliki tiga tahap. Tahap pertama, pengamatan lapangan. Dalam tahap ini peneliti mencatat data lapangan agar mampu memetakan masalah yang terjadi. Tahap kedua, proses evaluasi yang mendalam yang selanjutnya melakukan rekomendasi tindakan yang dapat dilakukan untuk mengatasi masalah yang ada. Tahap ketiga, menggunakan rekomendasi pada tahap kedua guna menghasilkan desain baru. Pada tulisan ini, menganalisis hasil temuan secara singkat dan rekondasi berupa konsep pemikiran bagaimana seharusnya Sekolah Menengah Umum Plus Al Wahid Kabupaten Tasikmalaya mewadahi kegiatan penggunanya.

\section{HASIL DAN PEMBAHASAN}

\subsection{Analisis Perancangan}

Kegiatan belajar mengajar yang dilakukan kurang lebih dilakukan 8 jam seharinya menunjukkan suatu pekerjaan yang berulang-ulang. Hal ini merupakan dasar bagaimana pentingnya kenyamanan di di dalam kelas, sehingga siswa dapat lebih fokus menikmati pelajarannya tanpa terganggu oleh dengan faktor-faktor yang menyebabkan ketidaknyamanan disekitarnya.

Untuk mengetahui seberapa nyaman, bagian mana yang sudah nyaman dan yang belum nyaman menurut penggunanya maka diperlukan alat pengumpul data berupa kuesioner. Kuesioner ini telah disebar kepada 67 orang siswa yang bertujuan untuk mengetahui tingkat kenyamanan sekolah serta mengetahui apa saja yang mereka harapkan agar sekolahnya bisa lebih nyaman digunakan. Penilaian untuk mengetahui tingkat kenyamanan yang dirasakan dibagi menjadi beberapa kategori yaitu: nyaman sekali, sedikit nyaman, tidak nyaman dan sangat tidak nyaman. Grafik persentase tingkat keluhan kenyamanan yang dirasakan siswa pada setiap ruangan dapat dilihat pada grafik 1 di bawah ini: 


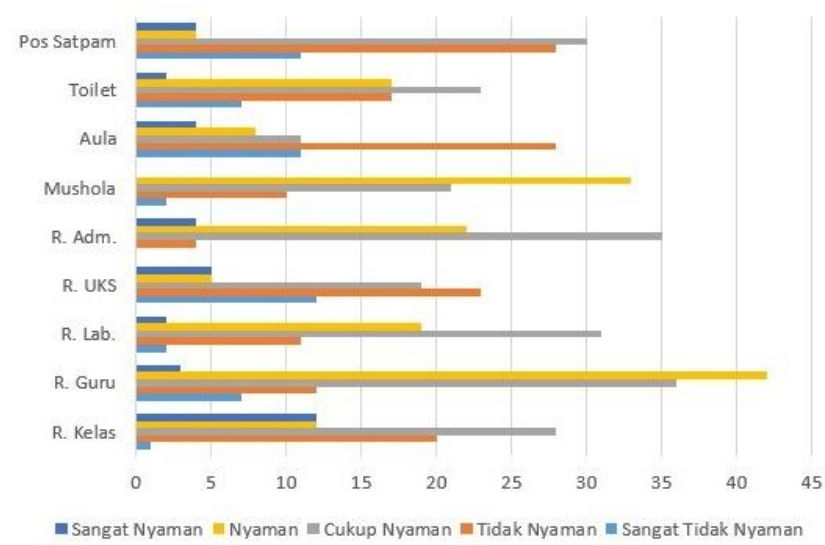

Grafik 1. Tingkat Kenyamanan Pengguna Sekolah

Dari grafik diatas terdapat beberapa ruangan yang dianggap nyaman dan ada pula yang dianggap tidak nyaman. Fasilitas sekolah yang dianggap tidak nyaman diantaranya Ruang UKS dan Aula. Fasilitas yang dianggap cukup nyaman diantaranya Parkir, Perpustakaan, Laboratorium, Ruang Administrasi, toilet, halaman dan lapangan. Fasilitas yang termasuk nyaman diantaranya ruang kelas dan bangunan secara keseluruhan. Hanya fasilitas Ruang Guru dan mushola saja yang dapat dikategorikan sangat nyaman. Dari hasil kuisioner tersebut bisa disimpulkan masih perlu adanya penanganan khusus untuk bangunan gedung sekolah tersebut terutama dari segi kenyamanan pengguna. Setelah mendapatkan data primer ini selanjutnya perlu dilakukan evaluasi untuk memperbaiki desain yang telah ada. Selanjutnya dilakukan analisis perancangan (tapak, iklim, pelaku, fungsi, bentuk rancangan) dan konsep perancangan yang akan dikembangkan.

a. Analisis Tapak. Analisis ini meliputi analisis tata ruang tapak kondisi tapak eksisting. Analisis ini dimulai dengan mengidentifikasi tapak perancangan yang terletak di daerah Kabupaten Tasikmalaya. Analisa tapak juga melingkupi program tapak yang terkait dengan fungsi dan fasilitas yang akan berpengaruh terhadap perencanaan bangunan.

b. Analisis Iklim. Analisis ini digunakan untuk mengetahui iklim di wilayah eksisting. Analisis ini mencakup analisa suhu, analisa cahaya dan analisa suara.
Ketiga elemen tersebut akan sangat berkaitan erat dengan konsep yang diambil yaitu bangunan berkonsep bioklimatik. Elemen tersebut akan menentukan bagaimana bentuk bangunan yang dirancang dengan penyesuaian tema.

c. Analisis Pelaku dan aktivitas. Analisis ini dilakukan untuk mengetahui aktivitas masing-masing kelompok pelaku yang menghasilkan besaran aktivitas tiap ruang. Analisis ini akan berpengaruh pada seberapa nyaman pelaku beraktivitas.

d. Analisis Fungsi. Metode ini merupakan kegiatan penentuan ruang yang mempertimbangkan fungsi dan tuntunan aktivitas didalam Sekolah. Proses analisis ini meliputi analisa pelaku dan aktivitas, ruang, persyaratan ruang, besaran ruang dan analisis organisasi ruang, aktivitas yang diwadahi oleh ruang.

e. Analisis Bentuk. Analisa bentuk dilakukan untuk memperoleh bentukbentuk yang sesuai dengan integrasi antara Sekolah SMA Plus Al-Wahid dengan konsep bioklimatik dan bangunan ramah lingkungan sebagai tema. Analisis ini dituangkan dalam bentuk sketsa dan program yang mendukung analisis

Tahap Evaluasi dilakukan setelah analisis konsep perancangan yaitu dengan mengkaji ulang kesesuaian analisis dan konsep perancangan yang nantinya akan digunakan sebagai acuan desain yang mengacu pada objek. Evaluasi konsep bangunan dan solusi yang dikembangkan sebagai berikut:

a. Pemanfaatan energi alami belum maksimal. Solusi: Lebih memaksimalkan energi alami dengan menggunakan bukaan dan shading shape

b. Potensi dan konsekuensi untuk lingkungan sekitar belum diperhatikan.

Solusi: Pengaturan ruang sirkulasi cahaya untuk bangunan yang ada disekitarnya

c. Ruangan panas pada kondisi dan waktu tertentu. Solusi: Membuat rekayasa bukaan untuk memanfaatkan udara alami. 
d. Pencahayaan pada beberapa ruangan masih kurang. Solusi: Memberi bukaan yang cukup agar cahaya bisa masuk yang disesuaikan dengan arah datangnya sinar matahari.

e. Pengelolaan air bersih masih kurang efektif. Solusi: Mengelola air bersih dengan baik dengan memberikan bak penampungan sebagai cadangan saat air ada gangguan.

f. Pemanfaatan dan penataan bagian luar bangunan (exterior) belum maksimal. Solusi: Memanfaatkan Secondary Skin pada bangunan dan sekitarnya dan vegetasi merambat untuk menambah nilai estetika bangunan.

\subsection{Konsep Perancangan}

Konsep rancangan yang dibuat mengedepankan beberapa hal berikut:

a. Prinsip ramah lingkungan, dengan penggunaan material alami, penerapan elemen-elemen lansekap pada tapak, akan tetapi adapula penggunaan material modern yang fungsional.

b. Menyesuaikan potensi tapak, memanfaatkan potensi dan sumber air pada tapak.

c. Hemat energi, memanfaatkan secara maksimal energi alami dengan memperhatikan orientasi matahari dan angin pada tapak, memberi bukaan pada bangunan, memberi jarak antar bangunan dan pemanfaatan system cross ventilation untuk memperlancar penghawaan dan pencahayaan alami.

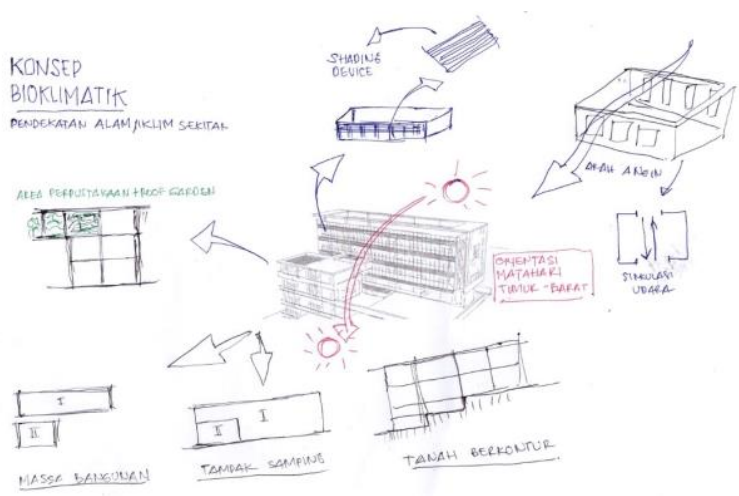

Gambar 1. Konsep Perancangan

\subsubsection{Gubahan Massa Bangunan}

Gubahan massa bangunan didapat dengan memaksimalkan bentuk eksisting, kebutuhan ruang, fungsi perancangan dan tema perancangan bangunan Bioklimatik. Bangunan terdiri dari dua gubahan massa bangunan yang saling berhubungan, massa pertama merupakan bangunan utama yang berfungsi sebagai kegiatan belajar mengajar siswa sedangkan massa kedua berfungsi untuk kegiatan admistrasi, ruang guru dan staf sekolah serta perpustakaan.

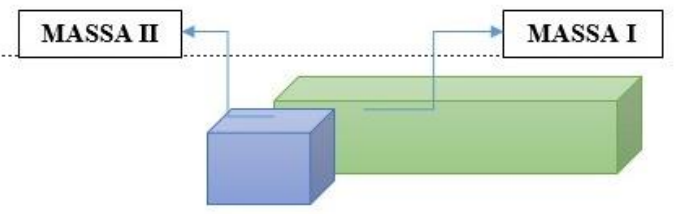

Gambar 2. Gubahan Massa Bangunan

\subsubsection{Explorasi Material}

Untuk bangunan sekolah ini material yang digunakan disesuaikan dengan kondisi lahan, potensi tapak dan penyesuaian dengan tema bioklimatik. Material yang paling banyak digunakan sebagai pembentuk kulit kedua bangunan ini adalah roster, kayu solid, kayu imitasi, besi hollow, laser cutting, kaca, dan bambu serta tanaman merambat. Lewat permainan bentuk, pola dan efek pencahayaan, secondary skin sangat cocok untuk diterapkan pada tema bioklimatik selain itu juga membuat fasad lebih estetis.

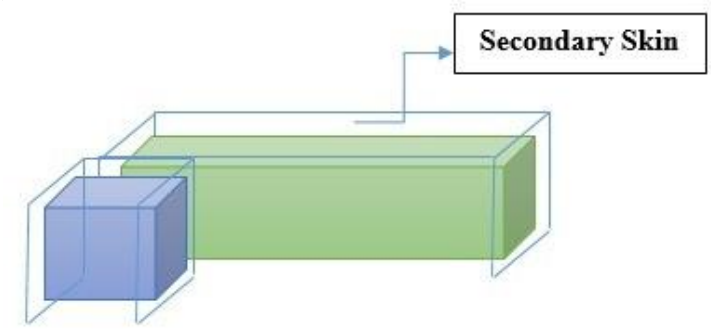

Gambar 3. Secondary Skin Pada Bangunan

\subsubsection{Konsep Pencahayaan}

Berdasarkan hasil analisa tapak, sisi timur dan barat yang paling banyak mendapatkan panas sinar matahari. Untuk meminimalisir meningkatnya suhu ruangan karena paparan matahari yang berlebih, maka untuk fasad bangunan yang mengarah barat akan diberikan shading vertical dan horizontal untuk menghalau panas matahari, sedangkan fasad bangunan sisi timur akan diberikan bukaan yang didesain sedemikian rupa untuk mengontrol cahaya yang masuk. 
Arah jendela tidak berhadapan langsung dengan arah sinar matahari.

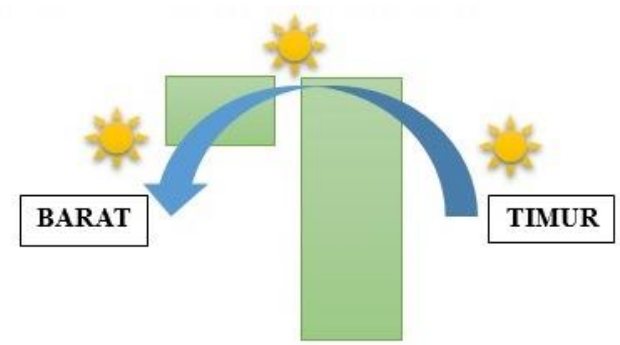

Gambar 4. Arah Pergerakan Matahari Terhadap Bangunan

Konsep orientasi ini dipilih karena sisi timur dan barat yang paling banyak mendapatkan panas sinar matahari. Pada sun shading device ini pula akan ditanam beberapa vegetasi merambat untuk memberikan efek segar bagi pengguna ruangan di dalam. Dengan pemberian shading device diharapkan mampu menekan panas matahari yang masuk ke bagian dalam gedung. Bentuk Sun Shading Device dapat dilihat pada Gambar 6 dan 7 dibawah ini.

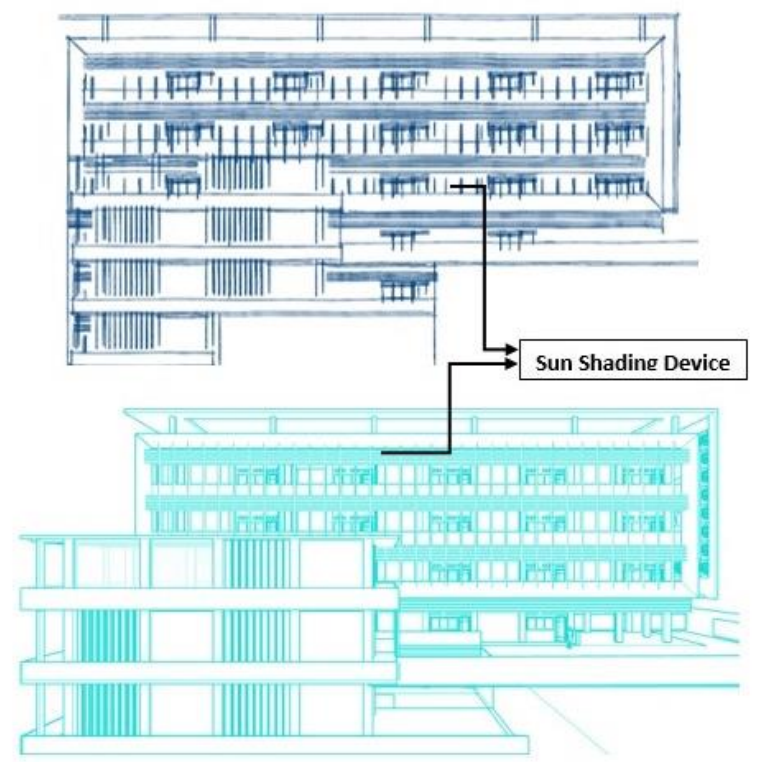

Gambar 5. Sun Shading Device sebelah Barat

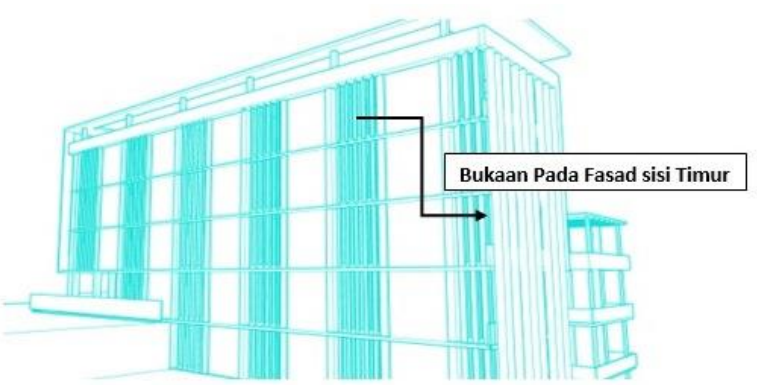

Gambar 6. Sun Shading Device sebelah Timur

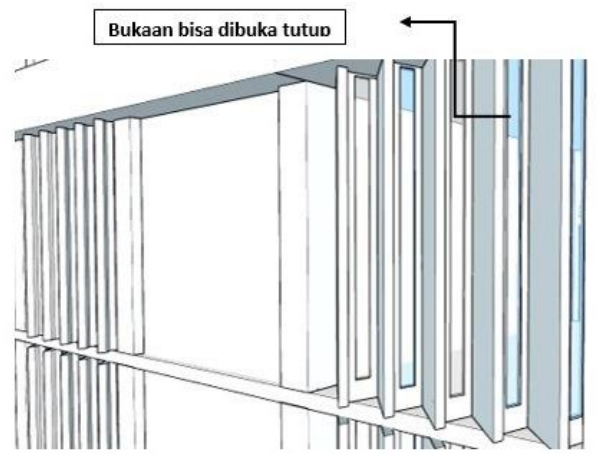

Gambar 7. Sun Shading Device Timur

\subsubsection{Konsep Angin}

Kabupaten Tasikmalaya mempunyai kecepatan angin yang cukup besar dengan arah bergerak dari selatan menuju utara. Hal ini bisa dimanfaatkan pada ruang-ruang yang membutuhkan penghawaan alami. Selain penghawaan silang, penghawaan alami dilakukan dengan cara mempertinggi jarak antara atap dan lantai sehingga udara dapat mengalir keatas dan dapat menghilangkan sumber panas. Selain itu bukaan juga sangat mempengaruhi masuknya angin, semakin besar bukaan, semakin besar juga angin yang bisa masuk kedalam ruangan. Kecepatan angin rata-rata di kawasan tapak $1,0 \mathrm{~m} / \mathrm{s}-3,0 \mathrm{~m} / \mathrm{s}$ sehingga dapat diambil kecepatan rata-rata angin di wilayah tersebut adalah 2,0m/s. Kecepatan angin tersebut dapat dimanfaatkan sebagai penghawaan alami. Selain bentuk bangunan, vegetasi juga bisa dimanfaatkan untuk penghambat laju angin. Sistem yang dipilih adalah sistem Two Openings Opposite Walls yang berfungsi sebagai sirkulasi udara alami sehingga udara atau angin dapat dimanfaatkan untuk penghawaan alami dalam ruangan. Di daerah Tasikmalaya rata-rata angin bergerak dari timur ke barat dan sebaliknya, oleh sebab itu fasad sisi timur dan barat 
didesain dengan bukaan - bukaan dan shading untuk mengontrol dan memanfaatkan hembusan angin.

\subsubsection{Konsep Kebisingan}

Kebisingan merupakan masalah penting yang harus diperhatikan karena akan mempengaruhi aktivitas belajar mengajar yang memerlukan ketenangan didalamnya. Dalam hal ini pemilihan solusi untuk kebisingan bisa dilakukan dengan pemilihan jenis vegetasi yang pengaturannya mengikuti konsep bangunan sehingga estetikanya juga terbentuk. Selain vegetasi, penggunaan beberapa material yang dapat menyerap atau meredam kebisingan pada bangunan dapat dipertimbangkan. Kebisingan yang sangat tinggi terjadi pada pagi hari, hal itu disebabkan karena aktivitas masyarakat sekitar, kendaraan yang lalu lalang sehingga menimbulkan aktivitas yang cukup ramai. Untuk mencegah kebisingan tersebut dipertimbangkan penggunaan vegetasi merambat dan partisi, serta pemberian jarak antar bangunan pada sumber bising sehingga dampak kebisingan dapat dikurangi.

\subsubsection{Pemilihan Warna pada Bangunan}

Pemilihan warna coklat diambil karena warna coklat adalah salah satu warna yang mengandung unsur bumi. Dominasi warna ini akan memberi kesan hangat, nyaman dan aman. Secara psikologis warna coklat akan memberi kesan kuat dan dapat diandalkan. Warna ini melambangkan sebuah pondasi dan kekuatan hidup. Selain warna cokelat, dipilih pula warna hijau. Warna hijau adalah warna yang identik dengan alam dan mampu memberi suasana yang santai. Berdasarkan cara pandang ilmu psikologi warna hijau sangat membantu seseorang yang berada dalam situasi tertekan untuk menjadi lebih mampu dalam menyeimbangkan emosi dan memudahkan keterbukaan dalam berkomunikasi. Hal ini diyakini sebagai efek rileksasi dan menenangkan yang terkandung dalam warna ini. Didalam bidang design warna hijau memiliki nilai tersendiri karena dapat memberi kesan segar dan membumi terlebih jika dikombinasikan dengan warna coklat gelap. Sedangkan warna beige diambil sebagai penyeimbang warna coklat agar bangunan tidak terlihat gelap dan memberikan kombinasi warna yang cukup baik. Warna -warna tersebut dipilih juga dengan pertimbangan tema yang dipilih yaitu bioklimatik yaitu pendekatan dengan ekologi dan alam sekitar. Jadi pemilihan warna yang diambil warna - warna yang ada kaitannya dengan alam supaya konsep bangunan bisa menyatu dengan alam sekitarnya.

\subsubsection{Pendekatan Bioklimatik pada Fasad}

Lokasi tapak sangat berpengaruh terhadap rancangan bangunan sehingga setiap daerah memiliki penanganan rancangan bangunan tersendiri berkaitan dengan lokalitas dan iklim sekitar. Fasad merupakan bagian terluar dari sebuah bangunan yang berfungsi sebagai kulit bangunan atau sebagai pemberi kesan pertama bagi pengunjung tentang fungsi dan desain bangunan. Dari analisis potensi tapak dan analisis iklim tersebut dapat dihasilkan acuan desain untuk mendesain fasad bangunan. Acuan ini akan mempengaruhi bentuk dan sistem bukaan pada bangunan termasuk fasad.

Selain menunjukan fungsional dari fasad bangunan sekolah ini dipasang ornamen kaligrafi yang bertuliskan Al-Wahid yang bertujuan sebagai identitas bangunan dan icon tersendiri. Diharapkan Fasad bangunan ini menjadi keunggulan tersendiri dibanding sekolah lain disekitarnya melalui perpaduan desain pemanfaatan energi alami yang ramah lingkungan.

\subsubsection{Pemilihan Material Yang Digunakan}

Material bangunan yang digunakan terutama pada fasad bangunan adalah bahan kayu. Tentunya jenis kayu hardwood yang memiliki daya tahan kuat terhadap pergantian cuaca. Maka kayu yang digunakan adalah kayu Ulin, kayu yang biasa di sebut kayu bulian atau kayu besi ini adalah kayu yang biasa digunakan untuk decting. Kayu yang tidak diragukan lagi kualitasnya. Selain itu ada juga kayu jati, kayu kruing, kayu bengkirai dan kayu merbau. Material yang digunakan pada bangunan sekolah SMA Plus Al-Wahid ini 
tidak semuanya dari kayu namun hanya beberapa elemen saja yang menggunakan kayu. Untuk elemen lainnya penggunaan beton dan ACP (Aluminium Composite Panel) dengan coating warna kayu.

Pada lantai paling atas bangunan sekolah terdapat area terbuka yang dikombinasikan dengan roof garden, area tersebut berfungsi untuk area baca siswa disaat istirahat dan kegiatan lainnya selain belajar mengajar. Dibagian atas ruangan kantor staff guru, terdapat ruangan perpustakaan yang didesain dengan 2 sistem ruang yaitu indoor dan outdoor. Jadi siswa bisa membaca didalam ruangan atau di luar ruangan, suasana membaca menjadi tidak membosankan. Orientasi ruang perpustakaan mengarah ke selatan dengan pemandangan gunung, sawah dan sungai yang akan memanjakan mata. Pada bagian belakang bangunan utama terdapat desain bukaan atau jendela yang unik yaitu bukaan yang didesain tidak langsung menghadap sinar matahari sehingga cahaya yang masuk kedalam ruangan pun tidak lurus namun dibelokan. Perspektif bangunan dapat terlihat pada Gambar 8 dibawah ini.

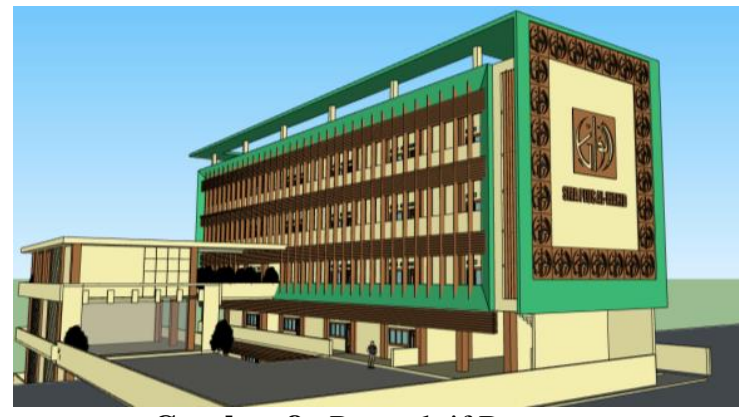

Gambar 8. Perspektif Bangunan

\section{KESIMPULAN}

Bentuk masa bangunan didesain untuk memaksimalkan potensi iklim terhadap tapak seperti matahari dan angin, sehingga mampu memaksimalkan energi alami dan meminimalisir penggunaan energi buatan. Hal ini sesuai dengan konsep bangunan bioklimatik, bentuk dan tampilan bangunan diusahakan memaksimalkan potensi energi alami yang ada baik itu udara, angin atau cahaya matahari. Untuk perancangan bentuk bangunan memaksimalkan kondisi tapak eksisting karena keterbatasan lahan yang tersedia. Penggunaan vegetasi merambat sangat disarankan untuk meminimalir kebisingan dan efek cahaya matahari yang berlebih. Diharapkan konsep bangunan sekolah di Indonesia pada umumnya dapat mengikuti potensi iklim yang ada di daerah masing-masing.

\section{REFERENSI}

Cahyaningrum, Hajar Kusuma. Hardiyati, Rachmadi N. (2017). Implementasi Prinsip Desain Arsitektur Bioklimatik pada Bangunan Perpustakaan di Klaten. Jurnal Arsitektura Universitas Sebelas Maret Surakarta, Volume 15 Nomor 2. Hal $434-438$.

Dewangga, Faiz. Purwanita Setijanti. (2016). Pendekatan Arsitektur Bioklimatik pada Bangunan Pesisir. Jurnal Sains dan Seni, Institut Teknologi Sepuluh Nopember, Volume 5 Nomor 2. Hal $184-187$.

Danisworo, M. (1989). Post Occupancy Evaluation, Pengertian dan Metodologi. Jakarta: Universitas Trisakti.

Peraturan Menteri Pendidikan Nasional Republik Indonesia No 24 Tahnu 2007 tentang Standar Sarana dan Prasarana untuk Sekolah Dasar/Madrasah Ibtidaiyah (SD/MI), Sekolah Menengah Pertama/Madrasah Tsanawiyah (SMP/MTs), dan Sekolah Menengah Atas/Madrasah Aliyah (SMA/MA).

Sudibyo, S. (1989). Aspek Fungi dan Teknis Post Occupancy Evaluation dalam Beberapa Metodologi Penelitian. Jakarta : Universitas Trisakti.

Yeang, Ken. (1994). Bioclimatic Skyscrapers. London : Artemis. 